\section{California counties adapt permitting and regulations for agritourism}

\author{
by Penny Leff
}

$C$ alifornia's 58 counties bear the primary responsibility for permitting and regulating agritourism operations on agricultural land within their boundaries. The counties often struggle with creating allowances and ease of permitting for agritourism businesses while ensuring that agritourism is a supplemental (rather than primary) activity on a commercial farm or ranch. Regulations also must ensure that agricultural production and local residents are not adversely affected by tourism. Some counties have recently changed their general plans, zoning ordinances and staffing assignments to encourage agritourism and have created guides to agritourism permitting.

The Lake County general plan includes Goal AR-3, “To provide opportunities for agritourism that are beneficial to the county and its agricultural industry and are compatible with the long-term viability of agriculture." The countywide general plan in Calaveras

\section{References}

Brown DM, Reeder RJ. 2007. Farm-based Recreation, Statistical Profile. USDA Economic Res Rep 53. Washington, DC.

Bruch M, Holland R. 2004. A Snapshot of Tennessee Agritourism: Results from the 2003 Enterprise Inventory. Univ Tenn Ext Pub PB1747. Knoxville, TN. http:// cpa.utk.edu/pdffiles/PB1747.pdf (accessed Oct. 20, 2009)

Chesnutt TJ. 2007. Developing an Agri-Tourism Attraction in Alabama. Alabama Cooperative Ext Syst, CRD-83. Auburn, AL.

[CTTC] California Travel and Tourism Commission. 2007. Rural Tourism Strategic Plan (2007-13.) Sacramento, CA.

CTTC. 2008. Data Tables. Sources of Travel and Tourism Statistics. http://tourism.visitcalifornia.com/media/ uploads/files/editor/Research/2008_.

George H, Rilla E. 2008. Agritourism Enterprises on your Farm or Ranch: Where to Start. UC ANR Pub 8334. Oakland, CA. 4 p.

German C, et al. 2008. Expanding E-Commerce Opportunities for Farm Fresh Markets and Agri-Tourism Industries. AgMrc Special Projects Initiative. University of Delaware, Department of Food and Resource Economics, College of Agriculture and Natural Resources and Innovative Exchange. Newark, DE. agricultural operation.
County (Foothill and Mountain region) specifically allows, by right, on-site sales and tasting, and directs that the definition of agricultural operations allowed should be broadly construed. Solano County (Central Valley region) has designated new zoning that encourages agritourism in Suisun Valley, one of 10 county regions defined in its general plan.

Mariposa, Placer and El Dorado counties (Foothill and Mountain region) have involved farmers and ranchers on advisory committees that created ordinances to streamline permitting for agritourism operations while limiting the extent of allowed activities in proportion to the size of the primary

Potential agritourism operators often complain about the lack of coordinated information from different county regulatory departments. To address this problem, Marin County (North Coast region) contracts with UC Cooperative

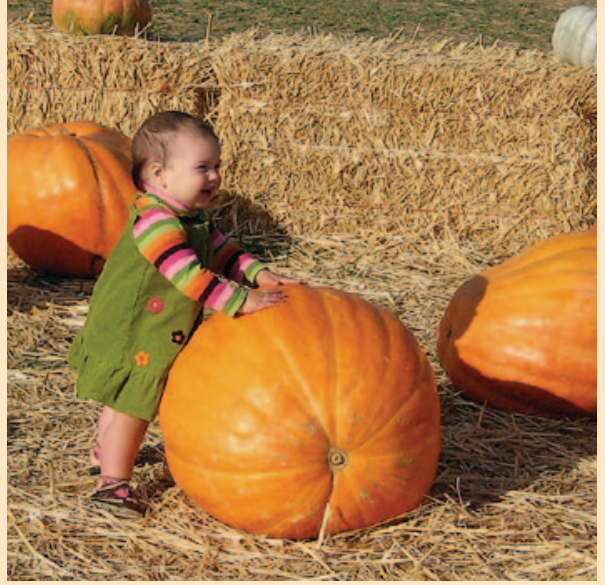

Regulators must strike a balance between promoting agritourism and ensuring that local residents are not adversely affected by traffic and other impacts. Above, a toddler visits Dave's Pumpkin Patch in West Sacramento.

Extension (UCCE) for an "agricultural ombudsman" to assist applicants with agriculture-related permitting. Marin County UCCE and Placer County staff created plain-language guides for farm-stay operations. Yolo County has created an Agricultural Permit Manual that describes all the permits that may be needed for various types of agritourism operations. More coordination among county departments and between counties would ease the regulatory burden on agritourism operators.

P. Leff is Agritourism Coordinator, UC Small Farm Program.
Hilchey D. 1993. Agritourism in New York State: Opportunities and Challenges in Farm-Based Recreation and Hospitality. Farming Alternatives Program, Department of Rural Sociology, Cornell University. Ithaca, NY.

Keith D, Rilla E, George H, et al. 2003. Obstacles in the agritourism regulatory process: Perspectives of operators and officials in ten California counties. AIC Issues Brief 22:1-6.

Klotz J. 2002. How to Direct-Market Farm Products on the Internet. www.ams.usda.gov/AMSv1.0/ getfile?dDocName.

Kuehn D. 2002. New York State's 1999 Agritourism Business Study. Proc 2001 Northeastern Recreation Res Symp, April 1-3, 2001, Bolton Landing, NY. USDA Forest Service Gen Tech Rep NE-289. Northeastern Forest Experiment Station. Radnor, PA.

Leonard J. 2008. Wildlife Watching in the U.S.: The Economic Impacts on National and State Economies in 2006. Addendum to the 2006 National Survey of Fishing, Hunting and Wildlife-Associated Recreation Report, 2006-1. US Fish and Wildlife Service. Arlington, VA.

Mace D. 2005. Factors Motivating Agritourism Entrepreneurs. Kansas State University, Dept of Agricultural Economics. Paper presented at 2005 Risk and Profit Conference, Manhattan, KS, Aug. 11-2. www.ag manager.info/events/risk_profit/2005/Mace.pdf.

Miller M. 2005. Agritourism Profile. lowa State University. www.agmrc.org/commodities_products/ agritourism/agritourism_profile.cfm (accessed Nov. 15, 2010).
Mirus S. 2009. States' Agritourism Statutes. National Agricultural Law Center, University of Arkansas. Fayetteville, AR. www.nationalaglawcenter.org/research. Ollenburg C, Buckley R. 2007. Stated economic and social motivations of farm tourism operators. J Travel Res 45(4):444-52

Reeder RJ, Brown DM. 2005. Recreation, Tourism and Rural Well-Being. USDA Economic Res Rep 7. Washington, DC

Rilla E. 1998. Unique Niches: Agritourism in Great Britain and Selected East Coast States. UC Cooperative Extension. Novato, CA. $68 \mathrm{p}$

Ryan S, DeBord K, McClellan K. 2006. Agritourism in Pennsylvania: An Industry Assessment. Center for Rural Pennsylvania. Harrisburg, PA. www.ruralpa.org/ agritourism2006.pdf (accessed Oct. 20, 2009).

[USDA] US Department of Agriculture. 2004. Agricultural Resource Management Survey. Economic Research Service. Washington, DC.

USDA. 2009. Income From Farm-Related Sources: 2007 State Data. National Agricultural Statistics Service. Washington, DC. www.agmrc.org/ commodities_products/agritourism.

Wine Institute. 2006. Report on Economic Impact of California Wine. MKF Research. San Francisco, CA www.wineinstitute.org. 